УДК 658.012 .4

JEL: 110, M10, 010

Міненко М.А.

доктор економ. наук, професор, ORCID ID: 0000-0002-7492-3196

Національний авіаційний університет

\title{
СТІЙКІ КОНКУРЕНТНІ ПЕРЕВАГИ В УМОВАХ ГЛОБАЛІЗАЦЇ̈ РИНКУ
}

\section{SUSTAINABLE COMPETITIVE ADVANTAGES IN CONDITIONS OF GLOBALIZATION OF THE MARKET}

Досліджуються існуючі підходи до забезпечення конкурентоспроможності підприємств (організачій, установ) на сучасному етапі ринкових відносин. Акцентується увага на загрозах, щзо виникли для вітчизняних господарюючих суб'єктів у зв'язку з євроінтеграційними прочесами, а також не бажанням власників та/або адміністративного менеджменту адекватно їх оцінювати $і$ приділяти належну увагу якісній побудові базової системи адміністративного менеджменту, добросовісній сертифікації на відповідність міжнародним стандартам, формуванню належного рівня ділової культури.

Доведено, що сертифікація на відповідність міжнародному стандарту $і$ навіть певній кількості міжнародних стандартів не гарантує стійкі конкурентні переваги у глобальному ринку. Виокремлено практичний досвід світових лідерів з виробництва товарів і надання послуг, який головним чинником стійкої конкурентоспроможності визначає ділову досконалість, організачійно-методичний зміст якої також необхідно регулярно інноваціонувати. Підкреслено, що базисом для изього прочесу $\epsilon$ система адміністративного менеджменту, яка спроможна підтримувати належний рівень адміністративної стабілізації. Для більш об'єктивної оцінки изього твердження введено до наукового обігу авторське визначення термінів: базова система адміністративного менеджменту; адміністративна стабілізація. Концептуально розкрито зміст японської (імені Е. Демінга) та американської (імені М. Болдріджа) моделей досконалих (ідеальних) організацій, а також моделі досконалості Європейського фонду управління якістю (EFQM Excellence Model) і загальної схеми оцінювання (Common Assessment Framework $(C A F))$. Обгрунтовано, щу досягнення якісного рівня ділової досконалості повинно розпочинатися з моменту зародження підприємства (організаиії, установи), а побудова моделі ідеальної організації має проходити поетапно: формування базової системи адміністративного менеджменту; впровадження ощадливого виробництва; забезпечення ефективного планування ресурсів; сертифікаиія на відповідність міжнародним стандартам; дотримання вимог міжнародних регламентів; побудова моделі ділової досконалості.

Ключові слова: стійкі конкурентні переваги; базова система адміністративного менеджменту; адміністративна стабілізація; сертифікація на відповідність міжнародному стандарту; модель ділової досконалості.

Existing approaches to ensuring the competitiveness of enterprises (organizations, institutions) at the present stage of market relations are investigated. Attention is focused on the threats emerged for domestic business entities in connection with European integration 
processes, as well as not the desire of owners and lor administrative management to adequately assess them and pay due attention to the qualitative construction of the basic system of administrative management, honest certification for compliance with international standards, the formation of a proper level of business culture.

It is proved that certification for compliance with an international standard and even a certain number of international standards do not guarantee sustainable competitive advantages in the global market. The practical experience of world leaders in production of goods and provision of services is singled out, which determines business perfection as the main factor of sustainable competitiveness, the organizational and methodological content of which also needs to be regularly innovated. It is emphasized that the basis for this process is an administrative management system which is capable of maintaining an adequate level of administrative stabilization. For a more objective assessment of this statement, into scientific circulation the author's definition of terms was introduced: the basic system of administrative management; administrative stabilization. Conceptually, the content of the Japanese (named after E. Deming) and the American (named after M. Baldrige) models of perfect (ideal) organizations, as well as the model of excellence of the European Foundation for Quality Management (EFQM Excellence Model) and the Common Assessment Framework (CAF)) are revealed. It is substantiated that the achievement of a qualitative level of business perfection should begin from the moment of the birth of the enterprise (organization, institution), and the construction of the model of the ideal organization should be carried out in stages: formation of the basic system of administrative management; introduction of economical production; ensure effective resource planning; certification for compliance with international standards; compliance with the requirements of international regulations; building a model of business excellence.

Keywords: sustainable competitive advantage; basic system of administrative management; administrative stabilization; certification for compliance with international standard; model of business excellence.

Вступ. Глобалізація ринкового простору спонукає виробників товарів i послуг до переосмислення стандартних підходів щодо реалізації стратегії і тактики своєї діяльності. Це у першу чергу пов’язано із можливими шляхами досягнення головного орієнтиру - конкурентоспроможності. Як показує практика, для забезпечення конкурентних переваг у сучасних умовах господарювання необхідно не тільки сформувати базову систему адміністративного менеджменту і бути сертифікованим на відповідність міжнародному(им) стандарту(ам) але й в обов'язковому порядку постійно перейматися питаннями ділової досконалості. Саме покроковий підхід до якісного розвитку системи управління може сприяти регулярному покращенню основних показників функціонування господарюючих суб'єктів.

Проблеми системного управління і ділової досконалості знайшли своє відображення у наукових працях вітчизняних й закордонних вчених, зокрема, Р. Бичківського, С. Гарковенка, П. Калити, М. Шаповала, М. Болдріджа, Дж. Джурана, Е. Демінга, А. Фейгенбаума та інших. Водночас комплексно питання покрокового вдосконалення систем управління залишаються постійно дискусійними. Автор пропонує свій варіант вирішення цієї проблеми.

Постановка завдання. Метою статті $\epsilon$ дослідження підходів щодо отримання конкурентних переваг підприємств (організацій, установ) в сучасних умовах господарювання i визначення покрокових дій, які 
забезпечуватимуть стійку конкурентоспроможність в умовах глобалізації ринку. Для досягнення поставленої мети пропонується вирішити наступні завдання: обгрунтувати загрози для національних суб'єктів господарювання у зв'язку із світовими глобалізаційними процесами; сформулювати можливі напрями розвитку систем управління, що сприятимуть стійкій конкурентоспроможності; визначити умови та етапи впровадження моделей ділової досконалості.

Методологія. Теоретико - методологічну основу дослідження становлять праці вітчизняних i зарубіжних вчених. Для досягнення визначеної мети було використано системний підхід, а також: методи аналізу і синтезу - при обгрунтуванні загроз і встановленні шляхів забезпечення конкурентних переваг; графічний метод - для наочного відображення базової моделі системи адміністративного менеджменту.

Результати дослідження. Чи можемо ми мати конкурентні переваги, сформувавши базову систему адміністративного менеджменту і будучи сертифікованими на відповідність міжнародному стандарту? Сьогодні це питання необхідно поставити першочерговим на порядок денний переважній більшості власників і керівників суб'єктів господарювання хто пройшов цю процедуру та отримав бажаний результат і всім тим хто планує це зробити. Особливо його актуальність зростає із наближенням періоду коли для національних виробників знімуть всі преференції щодо товарообміну 3 країнами Свропейського Союзу. Час монопольних переваг на ринку стрімко скорочується, що неминуче приведе до достатньо серйозних проблем, а можливо і до банкрутства. Критична ситуація, що склалась в Україні, у царині виробництва і надання послуг, має багато причин. Однією із головних $\epsilon$ та, що у більшості випадків і держава, і власники, і адміністративний менеджмент недбало, а досить часто й неадекватно відносяться до необхідності якісної побудови базової системи адміністративного менеджменту і сертифікації на відповідність міжнародним стандартам. На практиці, через недостатне розуміння, стандарти читаються досить спрощено, а їхні положення впроваджуються практично формально без урахування обов'язкової необхідності використання для цього цілісно регламентованої внутрішніми документами базової системи адміністративного менеджменту. У свою чергу ділова досконалість власниками і ТОР-менеджментом суб'єктів господарювання, як правило, не розглядається.

Відомо, що міжнародні стандарти орієнтовано на конкретні цілі, наприклад, якість продукції (послуг), збереження навколишнього середовища, безпеку умов праці, ефективність використання енергоресурсів тощо. Стандарти можуть використовувати будь-які підприємства (організації, установи). Вони сприяють удосконаленню систем менеджменту в цілому і систем адміністративного менеджменту зокрема, формуванню i прийняттю ефективних управлінських рішень, нівелюванню невизначеності в процесах співпраці з різними заінтересованими сторонами. Застосовувати 
стандарти доцільно для функціонування i розвитку відповідних сфер діяльності, наприклад: безпеки і якості продукції й послуг (ISO 9000); стану навколишнього середовища (ISO 14000); безпеки умов праці (OHSAS 18000); енергетичного забезпечення (ISO 50000) та інших.

При цьому слід розуміти, що за сучасних умов господарювання дотримання стандартів не гарантує конкурентні переваги на ринку. Особливо це характерно для власників та/або адміністративного менеджменту підприємств (організацій, установ), які обрали шлях їх спрощеного, не комплексного впровадження і використання. У підсумку це приводить до імітації вдосконалення через реалізацію неякісного, 3 точки зору вимог до процедур адміністрування, процесу сертифікації на відповідність будь-якому стандарту. Як результат - реальна ефективність фактично не підвищується, натомість формується стійке негативне ставлення до стандартів.

У зв'язку з цим варто підтримати думку президента Української асоціації досконалості та якості (УАДЯ) Петра Калити, який зазначив, що впровадження стандарту має бути не просто механістичним написанням відповідей на поставлені цим стандартом запитання, а одночасно супроводжуватися підвищенням рівня ділової культури організації. Попри все для фахового впровадження стандартів найбільш доцільно використовувати господарюючі суб'єкти, що відрізняються високою діловою культурою i мають базову систему адміністративного менеджменту, яка спроможна підтримувати належний рівень адміністративної стабілізації. На думку автора, адміністративна стабілізація - це зміна параметрів та/або структури базової системи адміністративного менеджменту, що призводить до набуття стійкості в результаті інтенсифікації затухання внутрішніх процесів та/або їх сталості (зміцнення), а також зменшення (мінімізації) впливу зовнішніх збурень на діяльність суб’єкта господарювання.

Сьогодні отримати сертифікат відповідності одному або навіть певній кількості міжнародних стандартів для багатьох підприємств (установ, організацій) не є недосяжною метою. Головне - бажання, ресурси, ринкова та/або репутаційна необхідність i сформована базова система адміністративного менеджменту. Як наслідок чисельність сертифікованих господарюючих суб’єктів в Україні з кожним роком зростає. Разом з тим, як вже зазначалося, сертифікованість не забезпечує стійкі конкурентні переваги для національних товаровиробників.

Саме тому президент УАДЯ П. Калита акцентує увагу представників вітчизняного бізнесу про необхідність усвідомити як аксіому : «Якщо при дефіциті норма стандарту - це верх вимог, то при насиченому ринку вона $є$ лише мінімальною умовою для збереження місця на ринку». Тобто стандарт - це не ідеал, а компроміс між сильними і слабкими сторонами, це мінімальна норма, прийнятна для насиченого ринку. Відповідність стандартам не гарантує довгострокової конкурентоспроможності на ринках, де конкурентна боротьба ведеться не стільки на рівні норм стандартів, скільки на рівні, що їх перевищує. Відповідність системи менеджменту 
підприємства (організації, установи) вимогам міжнародних стандартів сприяє підвищенню ефективності управління. Однак для конкуренції на насичених ринках цього може виявитися недостатньо. Системи менеджменту провідних європейських компаній більш просунуті, ніж передбачено стандартами. На практиці органи влади цивілізованих держав лише виставляють планки вимог до якості продукції (обов'язкові - на рівні регламентів, добровільні - на рівні стандартів), але долати ці планки, а також планки, що встановлюють споживачі, повинні самі підприємства шляхом досягнення прийнятного рівня своєї ділової досконалості $[1,2]$.

Дійсно, як показує практичний досвід світових лідерів 3 виробництва товарів i надання послуг, головним чинником стійкої конкурентоспроможності, в сучасних умовах господарювання, $є$ ділова досконалість, організаційно-методичний зміст якої також потрібно постійно інноваціонувати. Щоб мати стійкі конкурентні переваги необхідно створити базову систему адміністративного менеджменту, яка буде основою для сертифікації на відповідність міжнародним стандартам і для побудови моделі ділової досконалості. Така система, забезпечуючи сталий розвиток підприємства (організації, установи), повинна бути спроможною оперативно адаптуватися до будь-яких внутрішніх змін і до впливу факторів зовнішнього середовища. В авторському формулюванні базова система адміністративного менеджменту суб'єкта господарювання - це комплекс відносно відокремлених взаємозалежних елементів, що через налагоджені наскрізну підсистему комунікацій i документообігу, затверджені статут, штатний розпис, організаційну структурну схему управління, правилами внутрішнього трудового розпорядку, положення про структурні підрозділи, посадові інструкції (контракти, трудові угоди) і визначені виробничі завдання, шляхом реалізації функцій адміністративного менеджменту, використовуючи необхідний ресурсний потенціал, забезпечують досягнення цілей, які відповідають місії (візії, політиці) та обраній стратегії розвитку, не вступають у протиріччя із цінностями засновників та/або топ-менеджменту, нормами колективного та/або корпоративного договору, кодексу корпоративної етики, соціально-економічним і суспільно-політичним зовнішнім середовищем, законами, принципами i методами управління, a також сприяють дотриманню норм міжнародних стандартів (регламентів), що встановлюють умови господарювання конкретного підприємства (організації, установи) та $€$ основою для побудови моделі ділової досконалості (рисунок).

У свою чергу під діловою досконалістю в світі розуміють здатність господарюючого суб'єкта передбачати і задовольняти бажання та очікування всіх заінтересованих сторін. Рівень ділової досконалості характеризує, наскільки добре підприємство (організація, установа) це робить. Водночас, в інтерпретації Європейського фонду управління якістю, концепція ділової досконалості - це лідерство, засноване на баченні, натхненні й чесності, досягнення успіху завдяки талантам людей, додавання цінності для споживачів, побудова стійкого майбутнього, розвиток організаційних 
здібностей, використання творчості й інновацій, адаптивне управління, постійне досягнення видатних результатів [3]. Кращий світовий досвід визначення ділової культури суб'єкта господарювання, тобто - узагальнення кращої практики ведення справ, накопиченої в умовах насиченого ринку, відображено в сконцентрованому вигляді саме у фундаментальних концепціях ділової досконалості.

Для практичного використання концепції ділової досконалості застосовують моделі досконалих (ідеальних) організацій. Відомі сім основних моделей: австралійська, американська, європейська, ібероамериканська, індійська, сінгапурська, японська. Координація здійснюється в рамках Ради GEM (The Global Excellence Model Council). Найпоширеніші серед них: японська модель досконалості імені Е. Демінга; американська модель досконалості імені М. Болдріджа; модель досконалості Свропейського фонду управління якістю (EFQM Excellence Model); загальна схема оцінювання (Common Assessment Framework (CAF)).

Японська модель досконалості імені Е. Демінга [4] названа на честь статистика Едвардса Демінга, який під час роботи в Японії у 50-х роках двадцятого століття, здійснив значний внесок в японську економіку в частині розвитку якості. Після Другої світової війни завдяки зусиллям Демінга контроль якості став широко застосовуватися в японській промисловості. У деяких японських компаніях ці системи контролю трансформувалися в систему Загального контролю якості компанії, що базується на статистичному контролі якості. Зокрема, запропонований ним цикл i статистичні підходи до якості стали одними зі стовпів безперервного вдосконалення системи виробництва Toyota «точно в термін». В останні два десятиліття система виробництва Тойота стала більш широко відомою як «бережливе виробництво». Програма Е. Демінга базується на принципах задоволення споживача. Цикл Plan-Do-Check-Act (планування - виконання робіт - перевірка результатів (контроль) - коригувальні дії) та $є$ найбільш відомою як модель циклу прийняття рішень для поліпшення організаційних процесів і результатів.

Американська модель досконалості імені М. Болдріджа [5] названа ім'ям Мелкома Белдріджа, який був Секретарем торгівлі США з 1981 по 1987 рік. Він зробив величезний вплив на поліпшення i продуктивність роботи урядової адміністрації. Самоаналіз діяльності за критеріями Болдріджа допомагає оцінити чи розробляють і застосовують розумний, збалансований i систематичний підхід до управління організацією, наскільки добре менеджмент забезпечує досягнення поставлених цілей через процедуру реалізації спланованих завдань. Цю програму потрібно використовувати для дослідження процесів управління та їх впливу на кінцеві результати. 


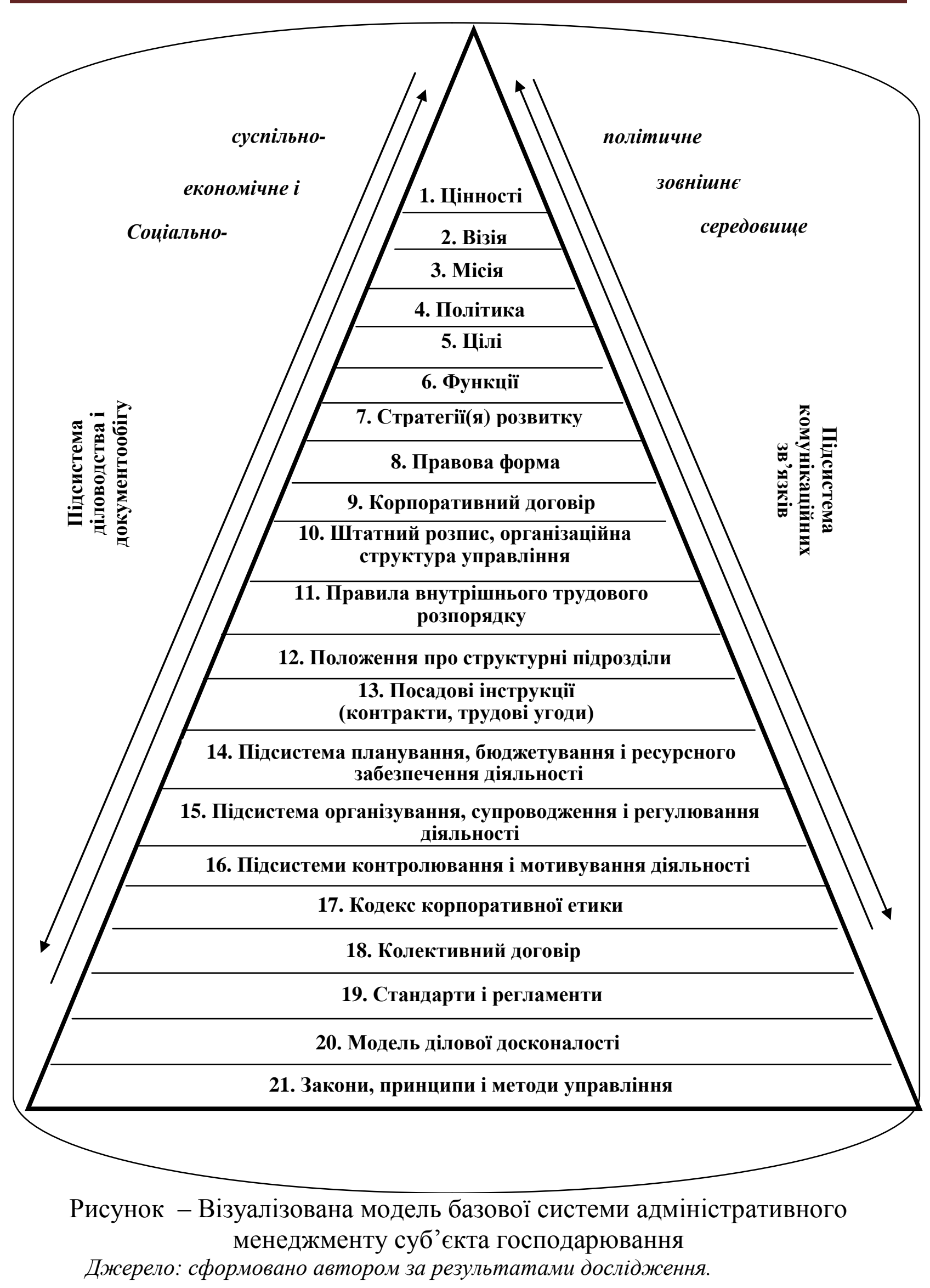


Вона передбачає підвищення значення якості в роботі американських інституцій за рахунок інформування інших компаній шляхом публікацій, проведення відкритих лекцій про хід і позитивні підсумки своєї роботи. Таким чином відбувається популяризація знань в області якості, що дає практичні результати для поліпшення економіки США. За допомогою Програми Болдріджа у США забезпечується глобальне лідерство в просуванні передових результатів, а також у навчанні та обміні успішними практичними прийомами, принципами і стратегіями. Основними критеріями досконалості продуктивності та якості являються: лідерство (керівництво); стратегії; клієнти; вимірювання, аналіз і керування знаннями; трудові ресурси; операції; результати.

Модель досконалості Європейського фонду управління якістю (EFQM Excellence Model) [6] - це практичний інструмент, який допомагає організаціям побудувати базову систему управління, визначити іiі місце на шляху до ділової досконалості, зрозуміти прогалини функціонування, прийняти необхідні рішення для досягнення успіху. Ключовими елементами даної моделі визначено якість, ефективність, сталість. Основою моделі EFQM $є$ концепція Загального управління якістю. Вона має універсальну структуру концепцій (ідей), що дозволяє господарюючим суб'єктам ефективно обмінюватися інформацією незалежно від сфери діяльності, рівня ділової культури та етапів життєвого циклу, на яких вони перебувають. Завдяки цьому суб'єкти господарювання, для розуміння власного рівня досконалості, можуть взяти за зразок позитивні практики іншої високоякісної організації.

Модель ідеальної організації EFQM складається з дев'яти критеріїв, що поділяються на п'ять факторів сприяння ділової досконалості і чотири фактори, що відображають іiі результати. П'ять факторів сприяння ділової досконалості суб'єкта господарювання вказують на можливості досягнення цілей завдяки: лідерству (керівництву); стратегії (політиці); персоналу; партнерству і ресурсам; процесам, продуктам(послугам). Чотири фактори результатів ділової досконалості вказують на досягнуті цілі: результати для клієнтів; результати для персоналу; результати для суспільства; результати для бізнесу.

Загальна схема оцінювання (Common Assessment Framework (CAF)) [7] концептуально повторює модель EFQM і пропонує інструмент, який допомагає європейським організаціям бюджетної сфери застосовувати методи управління якістю для поліпшення своєї діяльності. Модель об'єднує різні підходи до оцінки, аналізу і покращення діяльності організацій публічного сектору на основі вибору персоналу (через механізми самооцінки), вимірювання задоволеності різних груп заінтересованих сторін (у першу чергу, громадян (споживачів)), вивчення та обміну кращих практик. Дев'ять критеріїв моделі CAF відповідають основним вимогам, що приймають до уваги при аналізі будь-якої інституції. Зокрема, п’ять критеріїв щодо можливостей управлінської діяльності (лідерство (керівництво); 
стратегія і планування; персонал; партнерство і ресурси; процеси, продукти (послуги)) і чотири критерії щодо результатів (для клієнтів; для персоналу; для суспільства; для бізнесу). Змінюються вони через прямі показники сприйняття та оцінки ступеня задоволеності, а також через внутрішні показники результативності оцінки ситуації.

Концептуальний аналіз японської та американської моделей, а також моделей досконалості Свропейського фонду управління якістю дає підстави стверджувати, що певного якісного рівня розвитку господарюючих суб'єктів підприємці різних країн на різних континентах досягали ексклюзивно. Разом 3 тим головні елементи цих моделей, що фактично сприяють досягненню i забезпеченню стійкості конкурентних переваг окремих економік, заслуговують на високу оцінку. Попри всі позитивні міжнародні практики для національних виробників до цих пір залишається відкритим питання не вибору однієї із моделей на яку повинен бути зорієнтований їх менеджмент, а питання - чи необхідно взагалі моделі досконалості формувати будучи сертифікованими на відповідність міжнародним стандартам? Чим більше часу ми вагаємося, тим більше ми втрачаємо і втратимо.

Висновки. Узагальнюючи варто зазначити, що як процес сертифікації на відповідність міжнародному стандарту не може бути відокремлений від побудови базової системи адміністративного менеджменту, впровадження ощадливого виробництва i забезпечення ефективного планування ресурсів суб’єкта господарювання, так і будь-яку модель досконалого підприємства (організації, установи) не можна створити без повноцінно функціонуючої базової системи адміністративного менеджменту із використанням комплексу міжнародних стандартів (регламентів) на іiі основі. Це пояснює той факт, що шлях до ділової досконалості має проходити поетапно: формування базової системи адміністративного менеджменту; впровадження ощадливого виробництва; забезпечення ефективного планування ресурсів; сертифікація на відповідність міжнародним стандартам; дотримання вимог міжнародних регламентів; побудова моделі ділової досконалості.

Водночас на кожному із вказаних етапів, питання ділової досконалості доцільно не лише тримати у підсвідомості, а й впроваджувати на практиці, реалізуючи конкретні виробничі завдання. За рахунок таких послідовних кроків буде максимально раціонально та ефективно формуватися ділова культура суб'єкта господарювання, забезпечено його стабільні конкурентні переваги в сучасних умовах господарювання.

\section{Література:}

1. Калита П. Ділова культура формується й проявляється на двох основних рівнях: держави та безпосередньо організацій. Дзеркало тижня. 2018. №15. URL: https://dt.ua/macrolevel/bila-plyama-i-chorna-dira-v-ukrayinskiy-ekonomici-275775_html (дата звернення 10.01.2019 р.).

2. Калита П. Децентралізація - це не лише фінансова незалежність, а ще й конкурентноздатність регіонів. Дзеркало тижня. 2018. №20. URL: https://dt.ua/economics_of_regions/konkurentospromozhnist-regioniv-278864_html_ (дата 
звернення 10.01.2019 р.).

3. Шаповал М.І. Модель ділової досконалості підприємства Європейського фонду менеджменту якості. Менеджмент якості : навч. посіб. Київ : Знання, 2006. 471 с. URL: http://www.info-library.com.ua/books-text-9795.html (дата звернення 10.01.2019 p.).

4. Foresight University, The Foresight Guide, Shewhart's Learning and Deming's Quality Cycle. URL: http://www.foresightguide.com/shewhart-and-deming/ (Accessed 25.02.2019).

5. Baldrige Criteria for Performance Excellence Categories and Items. URL: https://www.nist.gov/baldrige/baldrige-criteria-commentary (Accessed 25.02.2019 p.).

6. EFQM Model. URL: https://www.toolshero.com/quality-management/efqm-model/ (Accessed 25.02.2019).

7. CAF: Common Assessment Framework. URL: http://am-one.ru/rd/pa/caf.html (дата обращения 25.02.2019 г.).

УДК 658.012.4:621

JEL класифікатор: $M 11$

Тупкало В.M.

доктор технічних наук, професор ORCIDID:0000-0002-6594-530X

Київський інститут інтелектуальної власності та права Начіонального університету «Одеська юридична академія»

\section{БІЗНЕС-СТІЙКІСТЬ ВИРОБНИЧОГО ПІДПРИСМСТВА: КОНЦЕПЦІЯ ТА МЕХАНІЗМ ЗАБЕЗПЕЧЕННЯ}

\section{BUSINESS-STABILITY OF MANUFACTURING COMPANY: CONCEPT AND MECHANISM OF SUPPLY}

У статті викладені розроблені автором концептуальні засади та обтрунтування моделі механізму забезпечення бізнес-стійкості виробничого підприємства на основі системного причинно-наслідкового характеру зв'язків системи бізнес-метрик управління підприємства з його комплексом маркетингу. Доведено, що кожна зі складових системи бизнес-метрик безпосередньо формує відповідні складові загальної моделі механізму забезпечення бізнес-стійкості. Тому пропонується бізнес-стійкість не зводити до синонімічно спрощено ототожнювання понять «фінансова стійкість» та "економічна стійкість», а розглядати стійкість як кортеж (комплекс) з трьох видів послідовно пов'язаних систем забезпечення стійкості «організачійна стійкість くринкова стійкість $\prec$ економічна стійкість», кожна 3 яких (система) складається з елементів функиіональних (операційних) видів стійкості. Пропонується формування чинників кожного з видів стійкості здійснювати иляхом логічного смислового об'єднання відповідної низки бізнес - політик Ріj як конкретних стратегічних поведінкових орієнтирів підприємства щчодо взаємодії з його цільовим ринком в рамках пари \{i - та бізнес - метрика, $j$ - та компонента маркетинг - мікс\}, кожний з яких (орієнтир) має економічно обтрунтований кількісний ключовий (інтегральний) показник. Визначено, щяо бізнес-стійкість - ие комплекс властивостей підприємства щэодо його спроможності швидко й адекватно реагувати на порушення в роботі технологічних бізнес-прочесів ланцююжа створення бізнес - иінності в контексті збереження довіри партнерів й 